\title{
Handbook of Florida Water Regulation: Toxic Substances Control Act ${ }^{1}$
}

\author{
Michael T. Olexa, Luke D'Isernia, Laura Minton, Dulcy Miller, and Sarah Corbett ${ }^{2}$
}

\section{Preface}

This handbook is designed to provide an accurate, current, and authoritative summary of the principle Federal and Florida laws that directly or indirectly relate to agriculture. This handbook should provide a basic overview of the many rights and responsibilities that farmers and farmland owners have under both Federal and Florida laws as well as the appropriate contact information to obtain more detailed information. However, the reader should be aware that because the laws, administrative rulings, and court decisions on which this handbook is based are subject to constant revision, portions of this publication could become outdated at anytime.

Several details of cited laws are also left out due to space limitations.

This handbook is distributed with the understanding that the authors are not engaged in rendering legal or other professional advice, and the information contained herein should not be regarded as a substitute for professional advice. This handbook is not all inclusive in providing information to achieve compliance with the Federal and Florida laws and regulations governing water protection. For these reasons, the use of these materials by any person constitutes an agreement to hold harmless the authors, the Florida Cooperative Extension Service, the Institute of Food and Agricultural Sciences, and the University of Florida for any liability claims, damages, or expenses that may be incurred by any person as a result of reference to or reliance on the information contained in this handbook.

\section{Overview}

The Toxic Substances Control Act (TSCA) of 1976 governs the following:

- Manufacturing.

- Disposal.

- Importing.

- Distributing.

1. This is EDIS document FE591, a publication of the Food and Resource Economics Department, Florida Cooperative Extension Service, Institute of Food and Agricultural Sciences, University of Florida, Gainesville, FL. Published December 2005. Please visit the EDIS website at http://edis.ifas.ufl.edu.

2. Michael T. Olexa, Professor, Food and Resource Economics Department, Florida Cooperative Extension Service, Institute of Food and Agricultural Sciences, University of Florida, Gainesville, FL; Director, Agricultural Law Center, University of Florida, Gainesville, FL; and Chair, Agricultural Law Committee of The Florida Bar. Luke D'Isernia, former student (graduated cum laude in 2005), Levin College of Law, University of Florida, Gainesville, FL. Laura Minton, Attorney, Dean, Mead, Egerton, Bloodworth, Capouano, and Bozarth, Orlando, FL. Dulcy Miller, attorney, Foley and Lardner, LLP, Orlando, FL. Sarah Corbett, Attorney, Florida Second District Court of Appeal, Lakeland, FL.

The Institute of Food and Agricultural Sciences (IFAS) is an Equal Opportunity Institution authorized to provide research, educational information and other services only to individuals and institutions that function with non-discrimination with respect to race, creed, color, religion, age, disability, sex, sexual orientation, marital status, national origin, political opinions or affiliations. U.S. Department of Agriculture, Cooperative Extension Service, University of Florida, IFAS, Florida A. \& M. University Cooperative Extension Program, and Boards of County Commissioners Cooperating. Larry Arrington, Dean 
- Using

- Processing of all toxic chemicals defined as those chemicals that present unreasonable risk of injury to public health or the environment.

TSCA requires that all such chemicals be inspected and approved by the Environmental Protection Agency (EPA) before they enter the market. The EPA has the option to restrict the chemical, run tests, and gather data during its pre-approval determination of whether the chemical represents a threat to health or the environment.

TSCA does not cover the following:

- Pesticides, and mixtures used as pesticides, that are covered by FIFRA.

- Tobacco or tobacco products.

- Certain nuclear materials, source or byproduct materials covered by the Atomic Energy Act of 1954.

- Chemicals that are covered by the Food, Drug, and Cosmetic Act.

- Any article which sale is subject to tax under the Internal Revenue Code of 1954.

All other chemicals, if they are not already on the EPA's approval list, are subject to review before they are released into the stream of commerce. The TSCA specifically dictates that the EPA must create restrictions for PCBs (the only chemical identified by name) as part of the mandate of TSCA.

The TSCA has a whistleblower provision that protects employees from being fired or discriminated against by their employers because the employee has initiated or is about to initiate a TSCA hearing, has testified or is about to testify in a TSCA hearing, or has or is about to participate or assist in any manner in a TSCA hearing or in any other action to carry out the purposes of TSCA.

\section{Who Enforces the TSCA?}

The EPA is the sole authority for enforcement of TSCA, although the TSCA specifically provides that the states are not prohibited from enacting their own legislation to regulate chemicals. The TSCA limits the state's power only to the extent that the state may not test new chemicals if the EPA is testing for the same purpose, and the state will be restricted in creating requirements which are different from those of the EPA concerning chemicals that have already been regulated by the EPA, unless the state is given authority to do so by the Clean Air Act or other federal law or it restricts the use of that chemical in that particular state.

\section{How Is the TSCA Enforced?}

The EPA schedule involves gathering information about a vast number of existing chemicals, the most suspect of which are subject to more extensive fact-finding.

Anyone introducing, importing, or manufacturing a new chemical must notify the EPA, as must anyone who obtains information which implies that a chemical represents a risk to health or the environment. All records, files, and documents are reviewed by inspectors to verify compliance.

The EPA may enact a wide range of restrictions upon suspect chemicals, including:

- Labeling/warning requirements.

- Limits on concentrations of manufactured quantities.

- Production/quality controls.

- Record keeping.

- Disposal criteria.

The TSCA also gives the EPA power to enforce its provisions by injunctions, restraint orders, forced inspections, and seizure of a product, as well as other means. The courts also have the power to restrain or force action on the part of producers to enforce TSCA. These powers are broader with respect to chemicals that are identified as posing an imminent and unreasonable risk of serious or widespread harm. Also, the EPA may require clean up of areas where violations resulted in environmental damage. 


\section{What Are the Penalties?}

The EPA has authority to impose civil administrative fines of up to $\$ 25,000$ for each separate violation of TSCA. Each day that a violation continues represents a separate violation. Also, willful or knowing violators may be subject to criminal penalties of up to $\$ 25,000$ per day per violation and/or up to one-year imprisonment.

\section{Exemptions from TSCA}

National Defense Waiver: The EPA Administrator will waive compliance with any provision of TSCA upon the request and determination by the President of the United States that the requested waiver is necessary in the interest of national defense.

\section{Source}

15 United States Code, Sections 2601 to 2671

\section{Acknowledgments}

The authors are indebted to the personnel of both state and federal agencies who provided their time and advice in the preparation of this handbook. The authors are especially indebted to Richard Budell of the Office of Agricultural Water Policy of the Florida Department of Agriculture and Consumer Services for providing funds for the development of this publication. 